\title{
Use of bioresorbable vascular scaffolds in patients with stable angina and acute coronary syndromes. Polish National Registry
}

\author{
Łukasz Rzeszutko ${ }^{1}$, Zbigniew Siudak ${ }^{2}$, Adrian Włodarczak ${ }^{3}$, Andrzej Lekston ${ }^{4}$, Rafał Depukat ${ }^{1}$, \\ Andrzej Ochała ${ }^{5}$, Robert J. Gil ${ }^{6,7}$, Wojciech Balak ${ }^{8}$, Miłosz Marć ${ }^{9}$, Janusz Kochman ${ }^{10}$, \\ Wojciech Zasada ${ }^{11}$, Dariusz Dudek ${ }^{2}$ \\ $1^{\text {nd }}$ Department of Cardiology, Institute of Cardiology, Jagiellonian University, Medical College, Krakow, Poland \\ ${ }^{2}$ Department of Interventional Cardiology, Institute of Cardiology, Jagiellonian University Medical College, Krakow, Poland \\ ${ }^{3}$ Miedziowe Centrum Zdrowia S.A., Lublin, Poland \\ ${ }^{4} 3^{\text {rd }}$ Department and Clinical Unit of Cardiology, Silesian Centre for Heart Diseases, Medical University of Silesia, Zabrze, Poland \\ ${ }^{5} 3^{\text {rd }}$ Department of Cardiology, Medical University of Silesia, Katowice, Poland \\ ${ }^{6}$ Invasive Cardiology Clinic, Central Clinical Hospital of the Internal Affairs and Administration Ministry, Warsaw, Poland \\ ${ }^{7}$ Institute of Experimental and Clinical Medicine, Polish Academy of Science, Warsaw, Poland \\ ${ }^{8} 2^{\text {nd }}$ Department of Cardiology, Ludwik Rydygier Collegium Medicum in Bydgoszcz, Nicolaus Copernicus University in Torun, Poland \\ 'Department of Cardiology, Municipial Hospital, Rzeszow, Poland \\ $101^{\text {st }}$ Department of Cardiology, Medical University of Warsaw, Warsaw, Poland \\ ${ }^{11}$ Krakow Cardiovascular Research Institute, Krakow, Poland
}

\section{Abstract}

Background: Current revascularisation guidelines recommend coronary stenting with either a bare metal stent or a drug eluting stent. The results of bioresorbable vascular scaffold (BVS) implantation in the setting of both stable angina and acute coronary syndrome (ACS) have proven to be both safe and efficacious.

Aim: To describe current use and real life experience among Polish percutaneous coronary intervention ( $\mathrm{PCl})$ operators in using BVS since they were made commercially available on our market.

Methods: We performed a one-arm retrospective observational registry study which enrolled patients in 30 invasive cardiology centres in Poland who had their PCl procedure performed between October 2012 and November 2013. All patients who received at least one BVS stent during index $\mathrm{PCI}$ were included in the registry. There were no additional inclusion or exclusion criteria.

Results: There were 591 patients enrolled in the registry in 30 centres in Poland. Of these, $48 \%$ were with stable angina (CCS I-III) and 52\% with ACS (23\% unstable angina, 18\% NSTEMI and 11\% STEMI). Radial access for PCI was used in $70 \%$ of cases. Left anterior descending was the target lesion in $48 \%$ of patients and predilatation used in $90 \%$. $\mathrm{PCl}$ complications occurred very rarely with dissection in $2.9 \%$ of patients, slow-flow in $0.5 \%$, no-reflow in $0.17 \%$, and side branch occlusion in $0.33 \%$. Technical success, defined as successful BVS delivery to the lesion, was achieved in all cases (100\%). There were no periprocedural deaths.

Conclusions: The early in-hospital results of this large scale national registry of 'real world' utilisation of BVS in Poland present excellent device performance in a properly selected group of patients with appropriate lesion preparation.

Key words: bioresorbable, stent, acute coronary syndrome, stable angina, registry

\section{Address for correspondence:}

Prof. Dariusz Dudek, 2 ${ }^{\text {nd }}$ Department of Cardiology, University Hospital in Krakow, ul. Kopernika 17, 31-501 Kraków, Poland, tel: +48 124247181 ,

fax: +48 1242471 84, e-mail: mcdudek@cyfronet.pl

Received: 07.04.2014 Accepted: 12.06.2014

Available as AoP: 04.07.2014

Copyright (C) Polskie Towarzystwo Kardiologiczne 


\section{INTRODUCTION}

Stent implantation has been proven to be superior to balloon angioplasty $[1,2]$. Current revascularisation guidelines recommend coronary stenting with either a bare metal stent (BMS) or a drug eluting stent (DES) as the method of choice for suitable atherosclerotic coronary lesions both in acute coronary syndromes (ACS) and stable angina [2, 3]. The results of many clinical trials, registries and meta-analyses have shown a significant reduction in mortality and target vessel revascularisation with DES compared to BMS also in long term observation [4-8]. Even though the target vessel revascularisation rates and occurrence of stent thrombosis is very low with the new generation of DES and there is less need for dual antiplatelet therapy, still the major drawback of coronary stent platform remains $[6,9]$. The implantation of a permanent stent scaffold is associated with irreversible changes and the impairment of endothelial function [10].

The notion of implantation of fully biodegradable scaffolds that allow for vessel wall regeneration and hopefully endothelial function recovery have became a reality in recent years with positive results from the family of ABSORB trials which have proven that the new bioresorbable vascular scaffolds (BVS) stent platform is both safe and efficacious [11-14]. The BVS has also been tested with positive results in the ACS setting, with outcomes comparable to classic drug-eluting metal stents [15].

Our aim was to describe the experience of using BVS in Poland since they were made commercially available on our market.

\section{METHODS}

We performed a one-arm retrospective observational registry study which enrolled patients in 30 invasive cardiology centres in Poland (see Appendix) who had their percutaneous coronary intervention ( $\mathrm{PCl}$ ) procedure performed between October 2012 and November 2013. Patients' blinded data was entered into the electronic case report form by collaborating physicians in these centres in an intense period of two weeks in November/December 2013. All patients who received at least one BVS stent during index $\mathrm{PCI}$ were included in the registry. There were no additional inclusion or exclusion criteria. Since this was a retrospective registry, there was no influence on the procedure itself as well as further treatment. Only baseline clinical and demographic characteristics of the patients, past medical history, angiography and $\mathrm{PCl}$ details as well as periprocedural and in-hospital outcomes are reported in this paper. Further clinical observation in long-term follow up is ongoing and will be addressed in future papers.

This study was executed in cooperation with an independent contract research organisation - Krakow Cardiovascular Research Institute (KCRI, Poland).
Table 1. Demographic and medical history of enrolled patients

\begin{tabular}{|lc|}
\hline Number of patients & 591 \\
Age & $60.6 \pm 10.3$ \\
Family history of CAD & $28 \%$ \\
Diabetes mellitus & $33 \%$ \\
Dyslipidaemia & $81 \%$ \\
Hypertension & $83 \%$ \\
Smoking & $41 \%$ \\
\hline
\end{tabular}

CAD - coronary artery disease

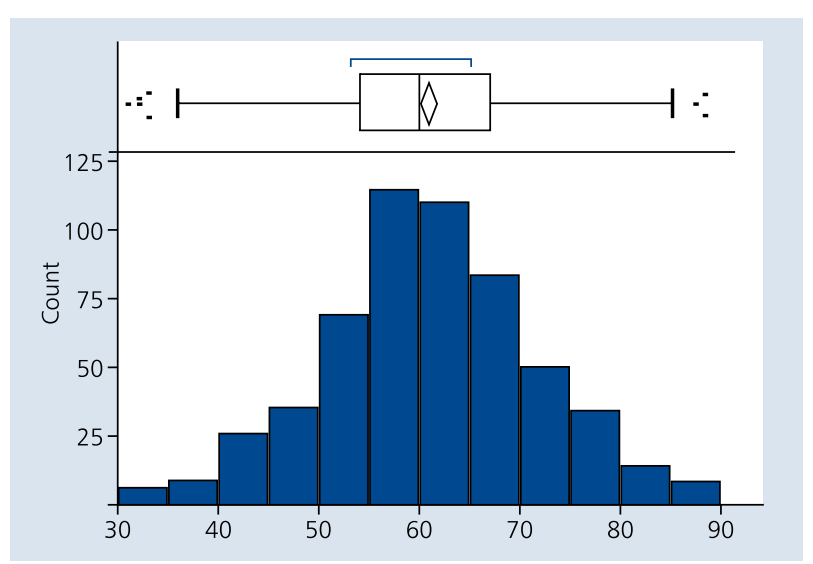

Figure 1. Age distribution in studied group

\section{Statistical methods}

Data was analysed according to the established statistical standards. Categorical variables were presented with counts and as percentages and continuous variables as means \pm standard deviation. All calculations were done with JMP 9.0.0 software.

\section{RESULTS}

There were 591 patients enrolled in the registry in 30 centres in Poland. Of these, $48 \%$ were with stable angina (CCS I-III) and $52 \%$ with ACS (23\% unstable angina, 18\% non-ST elevation myocardial infarction and $11 \%$ ST-elevation myocardial infarction). Baseline demographics and past medical history are presented in Table 1 and age distribution in Figure 1. Procedural details of angiography and lesion characteristics are described in Table 2. Of the $6 \%$ of arteries described as 'other' $42 \%$ were marginal branches, $40 \%$ diagonal branches, $10 \%$ saphenous vein grafts, $5 \%$ intermediate artery and $3 \%$ right posterior descending artery. The $\mathrm{PCl}$ procedure in detail is shown in Table 3. Sizing of coronary balloons for predilatation in relation to BVS stent diameter is depicted in Figure 2, whereas the pressures for postdilatation are shown in Figure 3. PCI periprocedural complications occurred very rarely, with dissection in $2.9 \%$ of patients, slow-flow in $0.5 \%$, no-reflow in $0.17 \%$, and 
Table 2. Details of angiography and lesion characteristics

\begin{tabular}{|c|c|}
\hline Radial approach & $70 \%$ \\
\hline \multicolumn{2}{|l|}{ Target lesion location: } \\
\hline LAD & $48 \%$ \\
\hline$C x$ & $19 \%$ \\
\hline RCA & $27 \%$ \\
\hline Other & $6 \%$ \\
\hline \multicolumn{2}{|l|}{ Lesion type: } \\
\hline$A$ & $28 \%$ \\
\hline B1 & $36 \%$ \\
\hline B2 & $22 \%$ \\
\hline$C$ & $14 \%$ \\
\hline \multicolumn{2}{|l|}{ Vessel tortuosity: } \\
\hline None & $32 \%$ \\
\hline Mild & $51 \%$ \\
\hline Moderate & $16 \%$ \\
\hline Severe & $1 \%$ \\
\hline \multicolumn{2}{|l|}{ Calcification: } \\
\hline None & $43 \%$ \\
\hline Mild & $41 \%$ \\
\hline Moderate & $15 \%$ \\
\hline Heavy & $1 \%$ \\
\hline \multicolumn{2}{|l|}{ Bifurcation lesion: } \\
\hline Side branch $<2 \mathrm{~mm}$ & $19 \%$ \\
\hline Side branch $>2 \mathrm{~mm}$ & $7 \%$ \\
\hline None & $74 \%$ \\
\hline \multicolumn{2}{|l|}{ Vessel sizing method: } \\
\hline IVUS & $1 \%$ \\
\hline IVUS + OCT & $3 \%$ \\
\hline OCT & $4 \%$ \\
\hline QCA & $31 \%$ \\
\hline Visual & $61 \%$ \\
\hline Predilatation & $90 \%$ \\
\hline
\end{tabular}

LAD - left anterior descending; Cx - circumflex; RCA - right coronary artery; IVUS — intravascular ultrasound; OCT — optical coherence tomography; QCA — quantitative coronary angiography

side branch occlusion in $0.33 \%$. Technical success, defined as successful BVS delivery to the lesion, was achieved in all cases $(100 \%)$. There were no periprocedural deaths. Dual antiplatelet therapy for 12 months was prescribed in $85 \%$ of patients, and only for six months in $15 \%$. In most cases, it was clopidogrel (86\%) that was added on top of aspirin with only sporadic cases of prasugrel (8\%) or ticagrelor (6\%).

\section{DISCUSSION}

Even though the clinical evidence of the safety and efficacy of fully BVS ABSORB is growing, most of the experience is still based on the results of single arm observational trials like ABSORB A\&B with 131 patients and Absorb Extend with 800 patients (results not published yet). Starting from 2012, when the BVS platform became commercially available, small
Table 3. Percutaneous coronary intervention procedure details

\begin{tabular}{|lc|}
\hline Variable & STEMI \\
\hline Number of implanted BVS stents: & \\
1 & $86 \%$ \\
2 & $11 \%$ \\
3 & $2 \%$ \\
4 or more & $1 \%$ \\
Postdilatation & $40 \%$ \\
Pressure & $16.9 \pm 3.0 \mathrm{~atm}$ \\
Technical delivery success & $100 \%$ \\
\hline
\end{tabular}

BVS - bioresorbable vascular scaffold; STEMI — ST elevation myocardial infarction

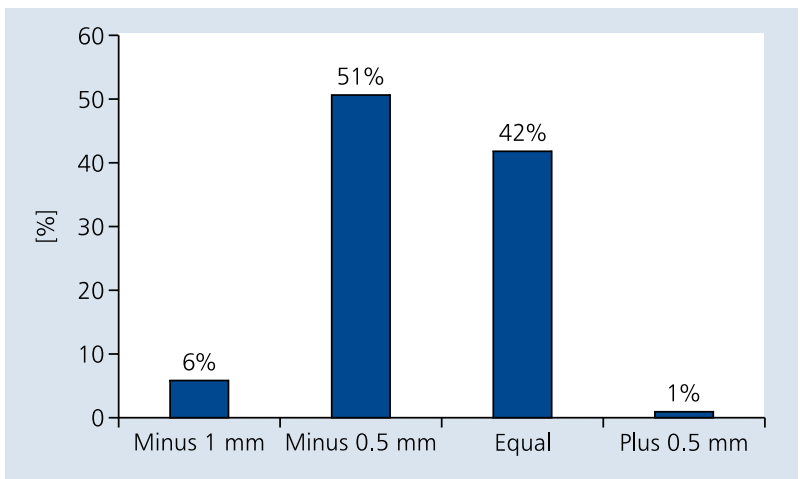

Figure 2. Diameter of coronary balloon used for predilatation in relation to bioresorbable vascular scaffold stent diameter

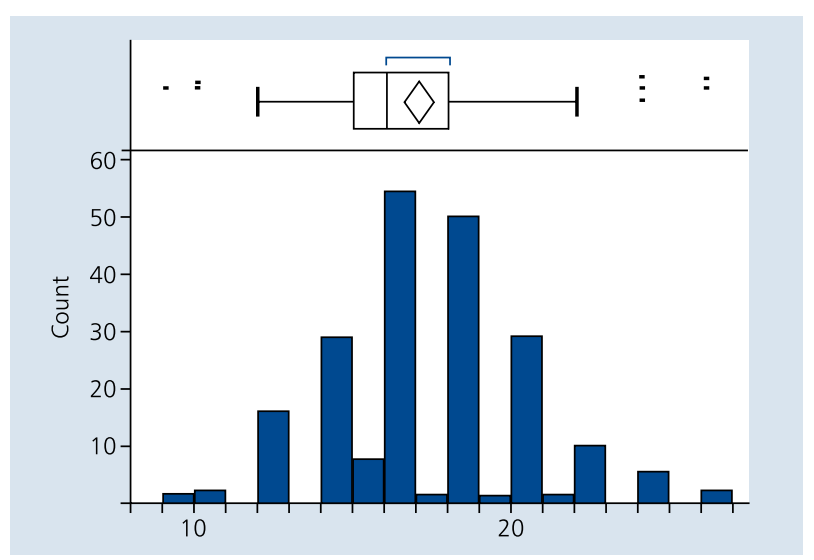

Figure 3. Postdilatation pressure distribution in studied group

registries especially focusing on the treatment of patients with ACS have been reported. Our registry is to date the largest investigator-initiated multicentre report of everyday usage of BVS in real life settings among a wider population of patients treated in 30 interventional cardiology centres in Poland.

The main finding of this report is high procedural success with commonly observed incidence of periprocedural com- 
plications in the selected patient cohort with implanted BVS. It may thus not reflect general ACS population outcomes. On the other hand, investigators' subjective perceptions of the technical implantation aspects were very favourable.

The low complication rate is probably related to different factors, with patient and lesion selection and procedural technique among the most important ones. Although the study population was young (mean age 60 years), there was a wide range of patients, from their 30s to their 80 s.

In the ABSORB A\&B, only patients with simple short lesions were included. The ABSORB Extend allowed using BVS in longer lesions. Among our cohort, the majority of patients had simple lesions A+B1 (64\%) while more complex - C (according to ACC/AHA lesion classification) were only found in $14 \%$. Proper lesion preparation with predilatation and high pressure inflations may play a crucial role in device performance.

Very low incidence of side branch occlusion was reported in the present cohort, in $0.33 \%$ of patients. According to the polled data from ABSORB cohort B and ABSORB Extend, this can vary between $1.7 \%$ and $10.5 \%$ and is related to the size of the side branch. In our cohort, $74 \%$ of dilated lesions were without any side branches involved and only in $19 \%$ of patients did the side branch at the culprit lesion have a diameter smaller than $2 \mathrm{~mm}$.

Edge dissection was reported in $2.9 \%$ of cases, but according to the ABSORB trials definitions, stenting due to dissection is not assessed as procedural failure. The mechanism of edge dissection was not validated, but the most common mechanism can be related to the vessel sizing or procedure technique. Although detailed quantitative coronary angiography (QCA) measurement of maximal vessel diameter in reference 'landing zones' — Dmax is strongly recommended, in the presented large cohort of patients QCA was done only in 31\% and other methods of sizing such as optical coherence tomography or intravascular ultrasound were used in $7 \%$. In the vast majority of patients $(61 \%)$, sizing was done based on visual assessment. However, it is important to note that only the most experienced operators performed these procedures and it will be very important to evaluate the efficacy and safety of such an approach also in the follow up data.

Procedural aspects important for the discussion were that in $10 \%$ of patients after lesion assessment the predilatation was omitted and direct stenting was performed. A similar number of direct stentings (9\%) was also reported in the POLAR ACS registry. In the remaining $90 \%$ of patients, predilatation was done and in $43 \%$ with more aggressive balloon sizing with the diameter equal or larger to the diameter of the planned BVS.

In $40 \%$ of patients, postdilatations were performed with high-pressure inflations. It is important to note here that during the time the registry was being conducted, the BVS sizing was limited to diameters of $2.5 \mathrm{~mm}, 3.0 \mathrm{~mm}$ and $3.5 \mathrm{~mm}$ and length from 6 to $18 \mathrm{~mm}$ (the latter one only in 2.5 and 3.0 diameters).

The small number of patients with moderate $(16 \%)$ or severe $(1 \%)$ vessel tortuosity as well as moderate $(15 \%)$ and heavy (1\%) calcifications at the culprit lesion and adequate lesion preparation allowed us to obtain $100 \%$ device delivery success in this selected patient population. On the other hand, our results were confirmed also in a greater variety of complex lesions.

In $15 \%$ of patients, even though the technology is more expensive than standard DES, operators decided to use more than one BVS device per patient. This looks especially attractive for patients with very long and diseased vessels to avoid full metal jacket as well in patients in whom one session multivessel BVS stenting offers the opportunity for full revascularisation and the return of normal vasomotion in the future.

In this multicentre registry, dual antiplatelet therapy (DAPT) strategy was mainly based on clopidogrel (86\%) and usually prescribed for 12-month therapy; six month DAPT was prescribed only in $15 \%$ of patients. The DAPT strategy after BVS is certainly worth additional investigation. The results of the German ACS registry have provided vital information that all cases of acute stent thrombosis were reported only on ticagrelor [15]. In the present registry, we report only procedural complications, and long-term observation is being collected.

\section{Limitations of the study}

The major limitation of this study is due to its non-randomised manner and all known drawbacks of registry studies. No angiographic analysis was performed and no long-term observation (beyond hospital discharge) is currently available, but it is ongoing and will be addressed in subsequent manuscripts.

\section{CONCLUSIONS}

The initial results of this large scale national registry of the 'real world' utilisation of BVS in Poland have presented excellent device performance in a selected group of patients with appropriate lesion preparation. BVS implantation in patients with a variety of clinical presentations ranging from stable angina to myocardial infarction is related to low complication rates.

\section{Conflict of interest: none declared}

\section{References}

1. Mahdi NA, Lopez J, Leon M et al. Comparison of primary coronary stenting to primary balloon angioplasty with stent bailout for the treatment of patients with acute myocardial infarction. Am J Cardiol, 1998; 81: 957-963.

2. Kolh P, Wijns W, Danchin N et al. Task Force on Myocardial Revascularization of the European Society of Cardiology (ESC) and the European Association for Cardio-Thoracic Surgery (EACTS); European Association for Percutaneous Cardiovascular Interventions (EAPCI), Guidelines on myocardial revascularization. Eur Heart J, 2010; 31: 2501-2555.

3. Steg PG, James SK, Atar D et al. ESC Guidelines for the management of acute myocardial infarction in patients presenting with ST-segment elevation. Eur Heart J, 2012; 33: 2569-2619.

4. Stettler C, Wandel S, Allemann S et al. Outcomes associated with drug-eluting and bare-metal stents: a collaborative network meta-analysis. Lancet, 2007; 370: 937-948.

5. Stone GW, Lansky A, Pocock SJ et al. Paclitaxel-eluting stents versus bare-metal stents in acute myocardial infarction N Engl J Med, 2009; 360: 1946-1959.

6. Kandzari DE, Leon MB, Meredith I et al. Final 5-Year Outcomes From the Endeavor Zotarolimus-Eluting Stent Clinical Trial Program: Comparison of Safety and Efficacy With First-Generation Drug-Eluting and Bare-Metal Stents. J Am Coll Cardiol Cardiovasc Interv, 2013; 6: 504-512. 
7. Dziewierz A, Siudak Z, Rakowski T et al. Drug-eluting versus bare-metal stents in ST-segment elevation myocardial infarction: a mortality analysis from the EUROTRANSFER Registry. Clin Res Cardiol, 2011; 100: 139-145.

8. Kirtane AJ, Gupta A, Iyengar S et al. Safety and efficacy of drug-eluting and bare metal stents: comprehensive meta-analysis of randomized trials and observational studies. Circulation, 2009; 119: 3198-3206.

9. Kim BK, Hong MK, Shin DH et al. A new strategy for discontinuation of dual antiplatelet therapy: the RESET Trial (REal Safety and Efficacy of 3-month dual antiplatelet Therapy following Endeavor zotarolimus-eluting stent implantation). J Am Coll Cardiol, 2012; 60: 1340-1348.

10. Hofma SH; van der Giessen WJ; van Dalen BM et al. Indication of long-term endothelial dysfunction after sirolimus-eluting stent implantation. Eur Heart J, 2006; 27: 166-170.

11. Brugaletta S, Radu MD, Garcia-Garcia HM et al. Circumferential evaluation of the neointima by optical coherence tomography after ABSORB bioresorbable vascular scaffold implantation: can the scaffold cap the plaque? Atherosclerosis, 2012; 221: 106-112.

12. Sarno G, Bruining N, Onuma Y et al. Morphological and functional evaluation of the bioresorption of the bioresorbable everolimus-eluting vascular scaffold using IVUS, echogenicity and vasomotion testing at two year follow-up: a patient level insight into the ABSORB A clinical trial. Int J Cardiovasc Imaging, 2012; 28: 51-58.

13. Depukat R, Rzeszutko L, Dudek D. Regeneration of vessel wall functionality and vascular restoration therapy with biodegradable stents: current status. Curr Pharm Biotechnol, 2012; 13: 2440-2448.

14. Serruys PW, Ormiston JA, Onuma Y et al. A bioabsorbable everolimus-eluting coronary stent system (ABSORB): 2-year outcomes and results from multiple imaging methods. Lancet, 2009; 14: 897-910.

15. Gori T, Schulz E, Hink U et al. Early outcome after implantation of Absorb bioresorbable drug-eluting scaffolds in patients with acute coronary syndromes. EuroIntervention, 2013 Sep 4, doi: pii: 20130825-02 [Epub ahead of print].

APPENDIX. Centers and Investigators according to the number of patients enrolled

Investigators

Adrian Włodarczak

Lech Poloński, Przemysław Trzeciak

Dariusz Dudek, Łukasz Rzeszutko, Rafał Depukat,

Wojciech Zasada, Zbigniew Siudak

Andrzej Ochała, Tomasz Roleder

Robert J. Gil, Jacek Bil

Władysław Sinkiewicz, Wojciech Balak

Miłosz Marć, Kamil Skoczyński

Janusz Kochman, Arkadiusz Pietrasik, Mariusz Tomaniak

Andrzej Cwetsch, Wojciech Wąsek, Wojciech Samul

Marek Król, Paweł Wieja

Krzysztof Reczuch, Artur Telichowski, Andrzej Szczepański

Zygfryd Reszka, Jakub Ostrowski, Edward Szulewski,

Gabriel Ruciński, Andrzej Skowroński, Michał Jaśkiewicz,

Wiesław Jary

Jacek Kubica, Michał Kasprzak, Adam Sukiennik

Marcin Gruchała, Dariusz Ciećwierz, Piotr Szargiej

Adam Młodziankowski

Henryk Danielewicz, Norbert Markiel, Piotr Danielewicz

Andrzej Kleinrok, Tomasz Domański

Marek Ujda, Grzegorz Hys, Paweł Procnal

Adam Kern

Mariusz Truszczyński

Paweł Jasionowicz

Janusz Prokopczuk, Jarosław Stachura, Stefan Sambor-

ski, Witold Babiński

Witold Żmuda, Piotr Czunko, Grzegorz Szastak

Rafał Wyderka

Adam Witkowski, Paweł Tyczyński

Jerzy Matysek, Jacek Jąkała

Gerard Grossmann, Waldemar Rumiński

Tomasz Barwiński

Piotr Kazimierczak, Przemysław Zieliński

Alicja Stańczak-Krop, Gerard Grossmann
Centres

Miedziowe Centrum Zdrowia S.A. w Lubinie

Śląskie Centrum Chorób Serca w Zabrzu

Szpital Uniwersytecki w Krakowie

Górnośląskie Centrum Medyczne w Katowicach

Centralny Szpital Kliniczny MSW w Warszawie

Szpital Uniwersytecki nr 2 im. dr Jana Biziela w Bydgoszczy

Szpital Wojewódzki nr 2 w Rzeszowie

Samodzielny Publiczny Centralny Szpital Kliniczny w Warszawie

Wojskowy Instytut Medyczny w Warszawie

I Oddział Kardiologiczno-Angiologiczny PAKS w Ustroniu

4. Szpital Wojskowy z Polikliniką we Wrocławiu

Wojewódzki Szpital Zespolony w Elblągu

Szpital Uniwersytecki nr 1 im. A. Jurasza w Bydgoszczy

I Klinika Kardiologii, Akademickie Centrum Kliniczne, Gdański Uniwersytet Medyczny

V Oddział Kardiologii Inwazyjnej i Angiologii PAKS w Mielcu

Regionalny Szpital Specjalistyczny im. dr. Wł. Biegańskiego w Grudziądzu

Samodzielny Publiczny Szpital Wojewódzki im. Papieża Jana Pawła II w Zamościu

Powiatowy Szpital Specjalistyczny w Stalowej Woli

Oddział Kardiologii Wojewódzkiego Szpitala Specjalistycznego w Olsztynie

NAFIS SA, Ośrodek Kardiologii Inwazyjnej w Lesznie

Nyskie Centrum Kardiologii Polsko-Amerykańskich Klinik Serca

IV Oddział Kardiologii Inwazyjnej, Elektrostymulacji i Angiologii; American Heart

of Poland, Kędzierzyn Koźle

Centrum Kardiologii Inwazyjnej, Elektroterapii i Angiologii w Oświęcimiu

Zgierskie Centrum Kardiologii MED-PRO

Instytut Kardiologii w Warszawie

Szpital Świętego Rafała w Krakowie

Wojewódzki Szpital Specjalistyczny w Lublinie

EUROMEDIC, Świętokrzyskie Centrum Medyczne w Końskich

Szpital Powiatowy w Radomsku

Szpital Specjalistyczny Ducha Świętego w Sandomierzu 


\title{
Zastosowanie stentów bioresorbowalnych w leczeniu chorych ze stabilną dławicą piersiową oraz ostrymi zespołami wieńcowymi. Doświadczenia polskich ośrodków
}

\author{
Łukasz Rzeszutko ${ }^{1}$, Zbigniew Siudak ${ }^{2}$, Adrian Włodarczak ${ }^{3}$, Andrzej Lekston ${ }^{4}$, Rafał Depukat ${ }^{1}$, \\ Andrzej Ochała ${ }^{5}$, Robert J. Gil ${ }^{6,7}$, Wojciech Balak ${ }^{8}$, Miłosz Marć9, Janusz Kochman ${ }^{10}$, \\ Wojciech Zasada ${ }^{11}$, Dariusz Dudek ${ }^{2}$ \\ 'Il Klinika Kardiologii, Instytut Kardiologii, Uniwersytet Jagielloński Collegium Medicum, Kraków \\ ${ }^{2}$ Klinika Kardiologii Interwencyjnej, Instytut Kardiologii, Uniwersytet Jagielloński Collegium Medicum, Kraków \\ ${ }^{3}$ Miedziowe Centrum Zdrowia SA, Lublin \\ 4III Katedra i Oddział Kliniczny Kardiologii, Śląskie Centrum Chorób Serca, Śląski Uniwersytet Medyczny, Zabrze \\ 5III Klinika Kardiologii, Śląski Uniwersytet Medyczny, Katowice \\ ${ }^{6}$ Klinika Kardiologii Inwazyjnej, Centralny Szpital Kliniczny MSW, Warszawa \\ ${ }^{7}$ Instytut Medycyny Doświadczalnej i Klinicznej, Polska Akademia Nauk, Warszawa \\ 8/l Katedra Kardiologii, Uniwersytet Mikołaja Kopernika w Toruniu, Collegium Medicum w Bydgoszczy, Szpital Uniwersytecki Nr 2, Bydgoszcz \\ ${ }^{9}$ Oddział Kardiologii, Szpital Wojewódzki nr 2, Rzeszów \\ ${ }^{10}$ Katedra i Klinika Kardiologii, Warszawski Uniwersytet Medyczny, Warszawa \\ ${ }^{11}$ Krakow Cardiovascular Research Institute, Kraków
}

\section{Streszczenie}

Wstęp: W aktualnych wytycznych dotyczących przezskórnej rewaskularyzacji wieńcowej zaleca się stentowanie jako metodę z wyboru leczenia istotnych zmian miażdżycowych w zakresie tętnic wieńcowych przy użyciu stenów typu BMS oraz DES. Wstępne wyniki badań z użyciem stentów bioabsrobowalnych (BVS) zarówno u chorych ze stabilną dławicą piersiową, jak i z ostrymi zespołami wieńcowymi potwierdzają ich bezpieczeństwo i skuteczność.

Cel: Celem badania było opisanie aktualnego zastosowania stentów typu BVS w codziennej praktyce klinicznej w Polsce po udostępnieniu ich przez producenta do obrotu komercyjnego.

Metody: W retrospektywnym badaniu obserwacyjnym wzięło udział 30 pracowni kardiologii inwazyjnej w Polsce, w których implantowano stenty typu BVS między październikiem 2012 a listopadem 2013 r. Każdy pacjent, który miał wszczepiony co najmniej 1 stent typu BVS, był zakwalifikowany do rejestru. Nie stosowano dodatkowych kryteriów włączenia i wyłączenia.

Wyniki: Zebrano dane dotyczące 591 osób. Objawy stabilnej dławicy piersiowej (CCS I-III) stwierdzono u 48\% z nich, a u pozostałych 52\% rozpoznano ostry zespół wieńcowy (niestabilna dławica piersiowa: 23\%, NSTEMI: 18\%, STEMI: 11\%). W 70\% przypadków zabieg wykonano z dostępu promieniowego. U 48\% chorych tętnicą docelową była gałąź międzykomorowa przednia, a predylatację stosowano w 90\% przypadków. Powikłania przezskrórnej interwencji wieńcowej występowały rzadko: dyssekcja u 2,9\% pacjentów, slow flow u 0,5\% osób, no-reflow u 0,17\% osób, a okluzja gałęzi bocznej u 0,33\% chorych. W 100\% przypadków badacze uznali, że zabieg zakończył się sukcesem. Nie odnotowano zgonów okołozabiegowych.

Wnioski: Wstępne wyniki tego narodowego rejestru pacjentów, którym implantowano stent typu BVS, pokazują praktykę kliniczną implantacji nowych stentów oraz skuteczność i bezpieczeństwo w wybranej grupie chorych po odpowiednim przygotowaniu zmian w tętnicach wieńcowych.

Słowa kluczowe: stent bioresorbowalny, ostre zespoły wieńcowe, stabilna dławica, rejestr

Kardiol Pol 2014; 72, 12: 1394-1399 